\title{
むだ時間を含む系の離散時間モデル作成法 ${ }^{\dagger}$
}

\author{
島 崎 潤 也* \\ A Method of Making a Discrete-Time Model for Continuous \\ System with Dead Time \\ Junya SHIMAZAKI*
}

\section{1.はじめに}

最近マイクロコンピュータを応用したディジタル制 御) が急速に発達し, 従来のアナログ制御では実現が 困難あるいは不可能であった高級な制御（予測制御, 適応制御，最短時間制御など）が可能となってきた. その際, 制御則は離散時間モデルをむとにディジタル 制御理論により設計されるので, 離散時間モデルの開 発が重要である. とてでは操作にむだ時間を含む系の 離散時間モデル作成法を考察する.むだ時間がサンプ リング時間の整数倍でない場合の取扱いは一般的な解 析が今まで行われていなかったが，以下に述べる状態 方程式を用いた方法が多変数系にも一般的に適用でき る. 例としては, プロセスの動特性を簡単なモデルで 近似するために，むだ時間プラス 1 次，2次遅れ系に 対する離散時間モデルを上記の方法により解析的に求 める.

むだ時間系のパルス伝達関数は拡張 $z$ 変換を用いて 導くことが可能であるが, 本論文の方法はより直接的 で高次系に適用でき数值計算上すぐれている. 最近の 論文 4) では, 状態方程式と拡張 $z$ 変換との関係を議 論しており, 状態方程式を利用している点では類似し ている.

\section{2. 状態方程式を用いたむだ時間の処理方法}

離散時間系のサンプリング時間を $\tau$, 対象プラント のむだ時間を $L$ とると，Lがてよりあ長い場合には

$$
L=m \tau+\tau_{1}, \quad 0 \leq \tau_{1}<\tau, m: \text { 整数 }
$$

と表わされる，そこで離散時間モデルは $m$ 個のむだ

†日本原子力研究所 茨城県那珂郡東海村白方白根 2-4

* Japan Atomic Energy Reseach Institute, Naka-gun, Ibaraki

(Received February 16, 1983)

(Revised May 24, 1983)

Keyword: discrete-time model, dead-time system, second order lag system with dead time, pulse transfer function
時間要素と $\tau_{1}$ の取扱いに分けて処理できる，m．個の むだ時間要素は状態変数をその数だけ増やすととによ り容易に処理できるので, $\tau_{1}$ の処理方法を考察する. 操作変数 $u(t)$ は $\tau_{1}$ の時間遅れにより, 任意のサンプ リング時間で Fig. 1 のように変化する（零次ホール ドを仮定して)，ここで区間 $[k \tau,(k+1) \tau], \quad k=0,1$, $2, \cdots$ に扔ける操作変数 $\tilde{u}(t)$ を

$$
\tilde{u}(t)= \begin{cases}u_{k-1}, & k \tau \leq t<k \tau+\tau_{1} \\ u_{k}, & k \tau+\tau_{1} \leq t<(k+1) \tau\end{cases}
$$

と表わすと, 状態方程式 $\dot{x}=A x+B \tilde{u}$ に対する離散 時間モデルの状態変数 $x_{k+1}$ は前の状態 $x_{k}$ と入力 $\tilde{u}(t)$ からつぎのように求まる.

$$
x_{k+1}=e^{A \tau} \cdot x_{k}+\int_{t_{k}}^{t_{k+1}} e^{A\left(t_{k+1}-t\right) B \tilde{u}(t) d t}
$$

(3) 式右辺の計算を実行し, 新たな行列を定義して簡 潔に表示すると, 次式を得る.

$$
\begin{aligned}
& x_{k+1}=F x_{k}+G_{1} u_{k-1}+G_{2} u_{k} \\
& \text { ここで, }
\end{aligned}
$$

$$
\begin{aligned}
& F=e^{A \tau}, \quad G=\int_{0}^{\tau} e^{A t} d t \cdot B \\
& G_{1}=G-G_{2}, \quad G_{2}=\int_{0}^{\tau_{2}} e^{A t} d t \cdot B, \quad \tau_{2}=\tau-\tau_{1}
\end{aligned}
$$

また $(4)$ 式を $z$ 変換で表わせば

$$
X(z)=(z I-F)^{-1}\left(G_{1} / z+G_{2}\right) U(z)
$$

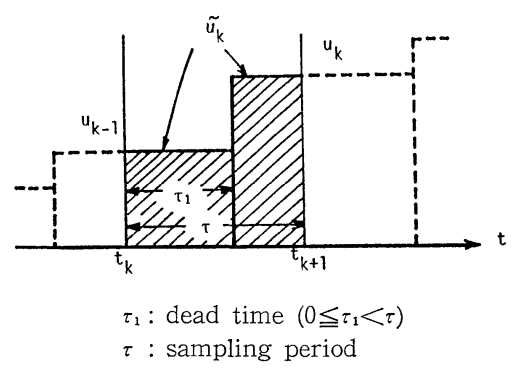

Fig. 1 Control variable between $t_{k}$ and $t_{k+1}$ in a discrete-time model with dead time 
となる.（7) 式に出力行列 $C(y=C x)$ を作用させれ ば直ちにむだ時間を含む多変数系のパルス伝達関数が 定まる.

$$
Y(z)=G(z) U(z)
$$

ここで,

$$
G(z)=C(z I-F)^{-1}\left(G_{1} / z+G_{2}\right)
$$

$(9)$ 式を用いれば，むだ時間 $\tau_{1}$ を含む伝達関数 $G(s)$ から対応するパルス伝達関数 $G(z)$ を導くことができ る.すすねわち，まず $G(s)$ からむだ時間を除いた系に 対して (可制御正準形, 可観測正準などの) 状態方程 式表示を求め, つぎにその状態方程式の行列 A, B , C およびむだ時間 $\tau_{1}$ から $(5),(6)$ 式を計算して，(9) 式によって最終的に $G(z)$ を求める.

\section{3. （むだ時間プラス 1 次， 2 次遅れ） 系のパルス伝達関数}

前章で述べた方法をむだ時間プラス 1 次遅れ系， 2 次遅れ系に適用して，それぞれのパルス伝達関数を求 める. 工業プロセスの動特性モデルとして，乙れらを 用いる近似は制御系設計などに有用であり，最近では むだ時間プラス 2 次遅れ近似が使用されている3). こ てでは 2 次遅れ系に対して, 非振動の場合（文献 2）に 本手法とは異なる方法が示されている）に加えて臨界 制動之振動の場合について考察し, 数值計算が直ちに 行える形に結果を整理して与える.なお，むだ時間 $L$ の扱いは前章と同様であるので, (1)式の $\tau_{1}$ の処理 だけを以下に述べる.

\section{1 （むだ時間プラス 1 次遅れ）系のパルス伝達関 数}

(むだ時間プラス1次遅れ)系の伝達関数 $G(s)$ は

$$
G(s)=e^{-\tau_{1} s /(1+T s)}
$$

で表わされる. 前章の方法によって，まずむだ時間を 除いた系に対して状態方程式をたてる。

$$
\frac{d x}{d t}=-\frac{1}{T} x+\frac{1}{T} u
$$

(5)，(6)式によりパルス伝達関数の作成に必要な諸 量を計算する.

$$
F=e^{-\tau / T}, \quad G=1-e^{-\tau / T}, \quad G_{2}=1-e^{-\tau_{2} / T}
$$

したがって，(9)式からパルス伝達関数はつぎのよう に求まる.

$$
G(z)=\frac{b_{0} z+b_{1}}{z^{2}+a_{1} z}
$$

こてで,

$$
\begin{array}{ll}
a_{1}=-p, & b_{0}=1-d, \quad b_{1}=d-p \\
p=e^{-\tau / T}, & d=e^{-\tau_{2} / T}, \quad \tau_{2}=\tau-\tau_{1}
\end{array}
$$

\section{2 (むだ時間プラス 2 次遅れ）系のパルス伝達関} 数

2 次遅れ系が非振動，臨界制動，振動のそれぞれの 場合について分けて考察する.

（1）非振動の場合

乙の場合の伝達関数 $G(s)$ は

$$
G(s)=e^{-\tau_{1} s} /\left\{\left(1+T_{1} s\right)\left(1+T_{2} s\right)\right\}, \quad T_{1}>T_{2}
$$

と表わされ，むだ時間を除いた状態方程式をつぎのよ うに定める.

$$
\frac{d}{d t}\left(\begin{array}{l}
x_{1} \\
x_{2}
\end{array}\right)=\left(\begin{array}{cc}
-1 / T_{1} & 0 \\
0 & -1 / T_{2}
\end{array}\right)\left(\begin{array}{l}
x_{1} \\
x_{2}
\end{array}\right)+\frac{1}{T_{2}-T_{1}}\left(\begin{array}{c}
-1 \\
1
\end{array}\right) u
$$

このようにすると，むだ時間を除いた $G(s)$ に対応す る状態方程式の各行列 $A, B, C$ はつぎのようになる.

$$
\begin{aligned}
& A=\left(\begin{array}{cc}
-1 / T_{1} & 0 \\
0 & -1 / T_{2}
\end{array}\right), \quad B=\frac{1}{T_{2}-T_{1}}\left(\begin{array}{c}
-1 \\
1
\end{array}\right), \\
& C=(1,1)
\end{aligned}
$$

したがって，パルス伝達関数の計算に必要な諸量は (5), (6)式加ら

$$
\begin{aligned}
& F=\left(\begin{array}{cc}
p_{1} & 0 \\
0 & p_{2}
\end{array}\right), \quad G=\frac{1}{T_{2}-T_{1}}\left(\begin{array}{c}
-\left(1-p_{1}\right) T_{1} \\
\left(1-p_{2}\right) T_{2}
\end{array}\right) \\
& G_{2}=\frac{1}{T_{2}-T_{1}}\left(\begin{array}{c}
-\left(1-d_{1}\right) T_{1} \\
\left(1-d_{2}\right) T_{2}
\end{array}\right) \\
& p_{1}=e^{-\tau / T_{1}}, \quad p_{2}=e^{-\tau / T_{2}}
\end{aligned}
$$

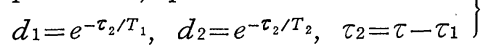

となり，パルス伝達関数 $G(z)$ はつぎのように求ま る.

$$
\begin{aligned}
& G(z)=(1,1)\left(\begin{array}{cc}
1 /\left(z-p_{1}\right) & 0 \\
0 & 1 /\left(z-p_{2}\right)
\end{array}\right) \\
& \times\left\{\frac{1}{z}\left(\begin{array}{c}
-\left(d_{1}-p_{1}\right) T_{1} \\
\left(d_{2}-p_{2}\right) T_{2}
\end{array}\right)+\left(\begin{array}{c}
-\left(1-d_{1}\right) T_{1} \\
\left(1-d_{2}\right) T_{2}
\end{array}\right)\right\} \\
& \text { - } \frac{1}{T_{2}-T_{1}} \\
& =\frac{b_{0} z^{2}+b_{1} z+b_{2}}{z^{3}+a_{1} z^{2}+a_{2} z} \\
& a_{1}=-\left(p_{1}+p_{2}\right), \quad a_{2}=p_{1} p_{2} \\
& b_{0}=1-\left(d_{1} T_{1}-d_{2} T_{2}\right) /\left(T_{1}-T_{2}\right) \\
& b_{1}=-\left(p_{1}+p_{2}\right)+\left\{d_{1}\left(1+p_{2}\right) T_{1}\right. \\
& \left.-d_{2}\left(1+p_{1}\right) T_{2}\right\} /\left(T_{1}-T_{2}\right) \\
& b_{2}=p_{1} p_{2}-\left(d_{1} p_{2} T_{1}-d_{2} p_{1} T_{2}\right)
\end{aligned}
$$

（2）臨界制動の場合

この場合の伝達関数 $G(s)$ は $G(s)=e^{-\tau_{1} s} /(1+T s)^{2}$

となり，（1）の場合と同様に取扱う。まず連続系状態 
方程式の各行列 $A, B, C$ を

$$
A=\left(\begin{array}{cc}
-1 / T & 1 \\
0 & -1 / T
\end{array}\right), \quad B=\left(\begin{array}{c}
0 \\
1 / T^{2}
\end{array}\right), \quad C=(1,0)
$$

と定め，(19)式に対応する諸量を計算する.

$$
\begin{aligned}
& F=\left(\begin{array}{cc}
p & \tau p \\
0 & p
\end{array}\right), \quad G=\left(\begin{array}{c}
1-(1+\tau / T) p \\
(1-p) / T
\end{array}\right), \\
& G_{2}=\left(\begin{array}{c}
1-\left(1+\tau_{2} / T\right) d \\
(1-d) / T
\end{array}\right) \\
& p=e^{-\tau / T}, \quad d=e^{-\tau_{2} / T}, \quad \tau_{2}=\tau-\tau_{1}
\end{aligned}
$$

したがって，パルス伝達関数 $G(z)$ はつぎのように求 まる。

$$
\begin{aligned}
& G(z)=\frac{b_{0} z^{2}+b_{1} z+b_{2}}{z^{3}+a_{1} z^{2}+a_{2} z} \\
& \text { ここで, } \\
& a_{1}=-2 p, a_{2}=p^{2} \\
& b_{0}=1-\left(1+\tau_{2} / T\right) d \\
& b_{1}=-2 p+\left(1+\tau_{2} / T\right) d+\left(1-\tau_{1} / T\right) d p, \\
& b_{2}=p^{2}-\left(1-\tau_{1} / T\right) d p
\end{aligned}
$$

（3）振動の場合

この場合の伝達関数 $G(s)$ は

$$
\begin{aligned}
G(s) & =e^{-\tau_{1} s /\left(T^{2} s^{2}+2 \zeta T s+1\right)} \\
& =e^{-\tau_{1} s}\left(\alpha^{2}+\beta^{2}\right) /\left\{(s+\alpha)^{2}+\beta^{2}\right\}
\end{aligned}
$$

のように表わされ，状態変数方程式は複素数領域での 表現を用いる. $A, B, C$ 各行列を

$$
\begin{aligned}
& A=\left(\begin{array}{cc}
-\alpha-j \beta & 0 \\
0 & -\alpha+j \beta
\end{array}\right), \quad B=\frac{j}{2 \beta}\left(\begin{array}{l}
1 \\
1
\end{array}\right), \\
& C=(1,-1), \quad(j=\sqrt{-1})
\end{aligned}
$$

と定め, (1)の場合と同様住計算するると, 最終的につ ぎのパルス伝達関数 $G(z)$ が求まる.

$$
\begin{gathered}
G(z)=\frac{b_{0} z^{2}+b_{1} z+b_{2}}{z^{3}+a_{1} z^{2}+a_{2} z} \\
\text { ここで, } \\
a_{1}=-p \cos \beta \tau, \quad a_{2}=p^{2} \\
b_{0}=1-d \sin \left(\beta \tau_{2}+\theta\right) / \sin \theta, \\
b_{1}=-2 p \cos \beta \tau+d \sin \left(\beta \tau_{2}+\theta\right) / \sin \theta \\
\quad-p d \sin \left(\beta \tau_{1}-\theta\right) / \sin \theta, \\
b_{2}=p^{2}+p d \sin \left(\beta \tau_{1}-\theta_{1}\right) / \sin \theta
\end{gathered}
$$

$$
\left.\begin{array}{l}
p=e^{-\alpha \tau}, \quad d=e^{-\alpha \tau_{2},} \\
\theta=\tan ^{-1} \frac{\beta}{\alpha}, \quad \tau_{2}=\tau-\tau_{1}
\end{array}\right\}
$$

(32)〜 (34)式は(30)式の表現における $\alpha, \beta$ からパル 不伝達関数を求めるあのであるが， $T, \zeta$ から求める ためには以下の式を用いればよい。

$$
\begin{aligned}
& a_{1}=-p \cos \left(\sqrt{1-\zeta^{2}} \tau / T\right), \quad a_{2}=p^{2} \\
& b_{0}=1-d \sin \left(\sqrt{1-\zeta^{2}} \cdot \tau_{2} / T+\theta\right) / \sqrt{1-\zeta^{2}}, \\
& b_{1}=-2 p \cos \left(\sqrt{1-\zeta^{2}} \cdot \tau / T\right) \\
& +d \sin \left(\sqrt{1-\zeta^{2}} \cdot \tau_{2} / T+\theta\right) / \sqrt{1-\zeta^{2}} \\
& -p d \sin \left(\sqrt{1-\zeta^{2}} \cdot \tau_{1} / T-\theta_{1}\right) / \sqrt{1-\zeta^{2}}, \\
& b_{2}=p^{2}+p d \sin \left(\sqrt{1-\zeta^{2}} \cdot \tau_{1}-\theta\right) / \sqrt{1-\zeta^{2}} . \\
& p=e^{-\zeta \tau / T}, d=e^{-\zeta \tau_{2} / T} \text {, } \\
& \left.\theta=\tan ^{-1} \frac{\sqrt{1-\zeta^{2}}}{\zeta}, \tau_{2}=\tau-\tau_{1}\right\}
\end{aligned}
$$

\section{4. 結 論}

むだ時間を含む連続系に対し，その離散時間モデル (多変数のパルス伝達関数) を求める方法を開発した. その方法は状態方程式を用いており，むだ時間が離散 時間系のサンプリング時間の整数倍でない場合に適用 できる，適用例ではプロセスの動特性近似において有 用なむだ時間プラス 1 次， 2 次遅れ系モデルに対し て，それぞれのパルス伝達関数を解析的に求めた，乙 の結果はプロセスのディジタル制御用モデルとして利 用でき，簡単な制御則を容易に定めたいような分散形 ディジタル制御に有用である.

\section{参 考 文 献}

1) 成田：ディジタルシステム制御，昭晃堂 (1981)

2) 高橋：システムと制御 第 2 版 上，下，岩波書店，199/ 201 (1978)

3） 戸荻, 高松：プロセスの 2 次達れ+むだ時間近似と DDC 系における制御パラメータの最適調整，計測自動制御学 会論文集, 16-3,405/411 (1980)

4) 美多, ほか: 状態方程式の $z$ 変換, 拡張 $z$ 変換とサンプ ル点間応答の一性質, 計測自動制御学会論文集, 18-9, 950/951 (1982) 